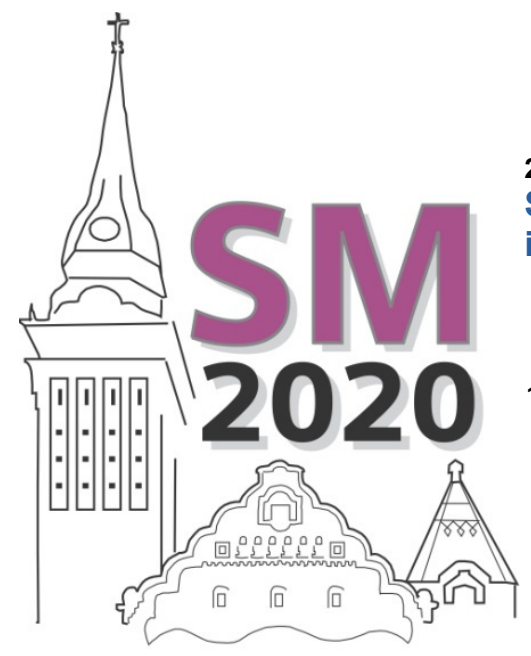

DOI: 10.46541/978-86-7233-386-2_2

25th International Scientific Conference

Strategic Management and Decision Support Systems

in Strategic Management

$19^{\text {th }}$ May, 2020, Subotica, Republic of Serbia

Mirela Panait

Petroleum-Gas University of Ploiesti

Bucarest, Romania

\section{Vasilii Erokhin}

Center for Russian and Ukrainian Studies,

School of Economics and Management,

Harbin Engineering University

Harbin, China

basilic@list.ru
Jean Vasile Andrei

Petroleum-Gas University of Ploiesti

Bucarest, Romania

andrei_jeanvasile@yahoo.com

mirela.matei@upg-ploiesti.ro

\title{
IMPLICATION OF TNCS IN AGRI-FOOD SECTOR - CHALLENGES, CONSTRAINTS AND LIMITS - PROFIT OR CSR?
}

\begin{abstract}
In completive economies, agriculture represents a vital sector in generating economic growth and provides significant employment for the rural population. Still, the recent transformation of the agricultural sector has generated massive debates on the implication of TNCs in providing sustainability and wellbeing for rural communities. The main aim of the manuscript is to provide a synoptic and integrative analysis of the implication of TNCs in agri-food sector by highlight the challenges, constraints and limits. The article outline a general framework of the main transformation of agri-food sector under the influence of foreign capital and present ways in which the CSR could be applied in agri-food sector for reducing discrepancies and poverty.
\end{abstract}

Keywords: transnational corporations, foreign direct investment, CSR, agri-food

\section{INTRODUCTION}

In the context predefined of the transformations of the global economy and of the orientation and readjustment of the classical economic structures TNCs has emerged as a determinant factor in drawing the new future trends. As already argued in literature (Andrei et al., 2015; Anghel et al., 2017) agriculture has becoming a lucrative economic factor with an extensive role in the domestic economies, not only limited in providing food for population but also it contributes to eradicating poverty in the rural communities, given the fact that a large number of people is living in poverty and suffering from hunger. Although is predominantly rural, agriculture incorporates into current practice the results of the technological and digital revolution by promoting and applying agricultural business models and innovative agronomic practices with a high degree of efficiency and productivity.

In contemporary economies, agriculture generates numerous public services and positive externalities, which although is difficult to be identified in the free market, act as a catalyst for rural economies, significantly contributing to the economic potential of rural communities. For numerous countries, agriculture continues to represent the basically economic branch capable to generate revenues for population in rural communities and the agricultural sector ensures the absorption of an important share of the local labor force. In this context, agriculture has become a vector in promoting sustainability and welfare in the rural communities.

As remarked in the literature (Heijman et al., 2019; Bowers and Cheshire, 2019; Vasile and Ungureanu, 2014), agriculture has to face new challenges imposed by the implementation of new production systems, climate change, price volatility or depopulation of rural areas, in which this sector is predominant in most cases. At the same time, new technologies impose the need for sectoral adaptation as part of either maintaining the competitiveness of the agricultural sector or reducing dependence on migrant labor in these areas. Also, as (Deblonde et al, 2007; Pandey et al, 2019; Borsellino et al, 2020;

How to cite: Panait, M., Erokhin, V., Vasile Andrei, J. (2020). Implication of TNCS In Agri-Food Sector - Challenges, Constraints and Limits - Profit or CSR?. In Proceedings of the 25th International Scientific Conference Strategic Management and Decision Support Systems in Strategic Management.

https://doi.org/10.46541/978-86-7233-386-2_2 
Jiang \& Chen, 2020; Yao et al, 2020; Zaman et al, 2020) highlights the unsustainable or unethical practices of agri-food corporations such as inhumane treatment of livestock, use of pesticides and fertilizers with consequences on environmental and food contamination, genetically modified crops, water usage and recycling, questionable practices (such as misleading or double standard offers on product quality sold in developed and developing countries), environmental pollution, monopolistic practices, small farm exclusion, improper working conditions, land use change and land grabbing.

Starting from the heterogeneous nature of agriculture, the implication effects of TNCs in the agri-food sector may be different, especially as the reaction of farmers is focused on ensuring the economic sustainability of their farms and less on CSR. In this context, the main of the article focuses on the activity of companies in the agi-food sector, constrained by the interests of shareholders, seeking to maximize profits and not being interested in long-term sustainable economic and on the other aspect, the need to SDD's fulfillment promoted by other categories of stakeholders. The novelty of this scientific approach is based on the analysis of the chameleon behavior of companies in the agri-food sector.

The mansucript is structured in two main sections. In the first section is analyzed the transformation of the agrifood sector from the perspective of foreign capital involvement, which completes and support the national efforts in financing the agricultural sector. The second section is dedicated to the analysis of the CSR strategies used by companies in the agrifood sector. Given the negative impact that companies in this sector have on the environment, the promotion of CSR programs is therefore a necessity.

\section{TRANSFORMATION OF AGRIFOOD SECTOR UNDER THE INFLUENCE OF FOREIGN CAPITAL}

In contemporary economies, the foreign capital has become a major financing support in numerous economic activities including in agricultural sector. Not always, the farmers have the financing support for developing their local business and farms and they had to address to alternative or foreigner capital sources. The foreign capital has brought not only the much needed financing of the agriculture but imposed dramatic sectorial changes. The foreign capital is attracted by a high degree of compensation and turnover and not always could be considered social responsible for increasing the rural communities wellbeing. In this context, as (Borsellino et al., 2020) remarks, the agri-food sector is in a complex process of transformation, under the action of several economic, social and environmental determinants, with convergent or divergent action (Borsellino et al., 2020). According to Reardon et al, 2009, the agri-food sector went through several restructuring stages that targeted specific areas, namely (1) wholesaling, mainly in the 1960s - early 1990s; (2) processing, mainly in the 1970s - 1990s; (3) and retailing, mainly in the 1990s - 2000s.

The changes that the agri-food sector is going through, generated by the technical progress, do not only concern the production process, but also the way in which the products are marketed and consumed. The activity in the agri-food sector has captured new values that are fueled by the transition from meeting basic food needs to pursuing by consumers, companies and other categories of stakeholders on issues related to human health or preservation of the environment (Sodano, 2019) considering the impact of food production and consumption. On the other hand (Da Silva, 2009, Sima and Gheorghe, 2018) shows that the increase of the population's income determine a considerable development and diversification of the demand for agri-food products, being able to identify new consumer behaviors that are oriented towards organic products, dietary products, green products, non-traditional fruits and vegetables or ethnic foods.

In literature (Ene, 2009; Jan, 2009; Stancu, 2012) often globalization is considered as another factor that contributes to the remodeling of the agri-food sector, with positive contributions on food security but also negative effects such as standardization of dietary patterns that could influence health, segmentation, relocation of different stages of production, the existence of global chains that could affect trasability of food products, dependence of the agro-food sector on the distribution sector.

As it is highlighted in (Jan, 2008, Aschemann-Witzel et al. 2015; Zaman et al, 2020), in developed countries, high living standards generate food waste, while in developing countries; much of the population is on the brink of poverty and lives in rural areas, where agriculture is a major source of livelihood. The increase in the demand for agri-food products has also favored the development of agro-industrial enterprises, a phenomenon observed mainly in developing countries. Process of agro-industrialization (Henson and Cranfield, 2009; Maertens and Fabry, 2019) is generated by consumer requirements, technical progress, liberalization of trade in agricultural products (Radulescu and Dumbravescu, 2008; Bojan et al, 2017; Voica and Panait, 2017; Borsellino et al., 2019) or liberalization capital movements (Matei, 2004).

The divers framework of economic agents involved in feeding foreign capital flows from the agricultural sector has diversified considerably, in addition to transnational companies making their presence felt and the investment funds and financial institutions that support the food security policy of governments that finance or consider investment in agriculture an opportunity not to be missed given the need to diversify the portfolio to reduce risk (Matei, 2004; UNCTAD, 2009; Panait et al., 2016).Foreign investors have nuanced their way of implantation in the agricultural sector over time, in the sense that in recent decades there has been a trend of land acquisition in developing countries (FDI in land) and less involvement in their activities. production and processing of agricultural products. This situation observed in both African and Central and Eastern European countries, generated by the weak capacity of public authorities to guarantee the right to food of the local population, paints a new profile of foreign investors who are considered land 
grabbers and which causes negative spillovers on local development and food security (Constantin et al., 2017; Santangelo, 2018).

The interest of foreign investors for certain host countries has faded over time and is no longer generated by the existence of fertile land, but by the availability of water resources that support the irrigation process. The lack of water and fertile land in some countries thus generates not only the intensification of trade in agri-food products (from countries that have a much better endowment with natural factors) and the emergence of virtual water trade and virtual land trade (Qiang et al, 2013 , Da Silva et al. 2016), but also the reconfiguration of foreign capital flows.

Numerous researches in the field (Chaudhuri and Banerjee, 2010; Slimane et al., 2016; Santangelo, 2018; Martin, 2019) remarks the negative effects that companies with foreign capital could generate on developing or transition countries in which they make investment. Adherents of the dependency theory emphasize the potential destructive effects that foreign investors could cause on host countries, fueled by bureaucracy, corruption and the weak involvement of public authorities in promoting the national interest. Thus, multinational companies present in the agri-food sector sometimes behave unethically by manipulating the price of products sold on the local market, using the transfer price mechanism, distorting costs or revenues in order to avoid taxes, repatriated profit to origin country.

According to the followers of the modernization theory, the multinational companies have become important actors on the agri-food market, and the foreign direct investment not only finance the agriculture from the developing countries, but have also ensured the transfer of technology, know-how, quality standards. direct implications on food safety, sales markets for finished products (Matei, 2004; Reardon et al, 2009). However, the generation of these positive spillovers in the economies of the host countries is particularly influenced by the ability of these countries to absorb the tangible and intangible resources offered by transnational companies, which depends on the reaction and involvement of the workforce and public authorities in the host country (Slimane, et al, 2015)

As it is a shown in literature (Santangelo, 2018; Hughes, 2019) foreign direct investment in the agricultural sector is generated by natural conditions (soil, water and climate conditions), provided by the host country. This type of investment is resource-oriented investment, and the different endowment of countries has direct consequences on the production, trade and financing process of agricultural activities. In fact, as (Gow and Swinnen, 1998; Matei, 2004; UNCTAD, 2009) describes, the first foreign investment made worldwide on the colonial era were generated by the expansion of European companies to the colonies, the motivation being the search for natural resources that were processed with cheap labor in the host countries, the main sectors being agriculture and extractive industry. Also, as (Bolling and Somwaru, 2001; Matei, 2004) argues, over time, the motivation of foreign investors has faded, with investment being made that seek access to a local or regional market or that generate products that are not sold for the local market but are exported. In fact, in agri-food sector, FDI is a cost-effective way to reach local markets, so this investment is efficiency seeking.

As (Bolling and Somwaru, 2001; Voica and Panait, 2017) states, the expansion of FDI in the field of agri-food was also generated by the emergence and consolidation of free trade areas and customs unions (NAFTA, MERCOSUR, EU) which led to a reorientation of the interest of foreign investors with free access to the regional market (facilitated by free movement of goods by signing trade agreements) focused on other countries in more remote regions.

Moreover, the interest of foreign investors has shifted from the production of agricultural products to upstream or supporting industries or downstream industries. So, TNCs are present in all segments of the global value chain - GVC as (Rueda et al, 2017; Maertens and Fabry, 2019) presents in their researches. Moreover, the emergence and development of the biofuels segment attracted new transnational companies that initially had nothing to do with the production of agricultural products. However, the production of biofuels is a rather controversial topic considering that agricultural lands are no longer used to meet the food needs of the population, but to generate products used for energy as it si argued by Dusmanescu, (2013) or Ene et al., (2017).

The liberalization of capital movements internationally was also reflected in the increase in FDI flows concentrated in the agricultural sector, the maximum being reached in 2007. After this peak, the overlap of the international financial crisis and the food crisis of 2008 dramatically affected foreign capital inflows until year 2011, after which FDI flows remain on ascendent trend. FDI flows oriented towards the industrial processing sector of agricultural products (food, bevareage and tobacco) have experienced, since 2008, a less dramatic decrease compared to those in agriculture and later an evolution of the sawtooth type (FAO, 2020).

In addition, national policies contribute to improve the spillover effect of foreign investmetn on host economies deepening or improving these difference. According to FAO statistics, the countries were divided into net exporting countries of agricultural products, net importing countries, and there is a group of countries that have natural resources, but the lack of proper use of natural resources and low involvement of public authorities in supporting The process of investing and financing them makes these countries import large quantities of agricultural products to meet the needs of the population. (UNTAD, 2009). The best example in this sense is Romania, which despite its special agricultural potential is listed as a net importer of agricultural products. These countries need massive investments, technology transfer and knowledge to increase labor productivity and improve the share of arable land used.

In the top of the most attractive countries for foreign investors are those countries that have fertile agricultural land, generally developing countries such as China, Argentina and Indonesia. Romania ranks 10th in the top of foreign direct investment attracted to agriculture, but imports large quantities of agricultural products which demonstrates the speculative nature of attracted investmentsin the sense that investors bought agricultural land but do not use it for agricultural production but as an asset financially necessary to diversify and reduce portfolio risk. (FAO, 2020). From the point of view of the countries that attracted the most important FDI flows in agri-food sector, the top 10 is ruled by developed economies, with a strong industrial sector (SUA, Netherlands, UK, Spain, Italy, France). 
The problem of budgetary constraints specific to developing countries and poor financing of the agricultural sector could be solved by attracting foreign direct investment. But also in this field, the attitude of public authorities towards foreign direct investment is nuanced, there are countries that allow access to foreign investors but also countries that restrict the presence of foreign capital for strategic reasons related to food security. Unfortunately, worldwide, experts believe that agriculture is a neglected engine for development (UNCTAD, 2009).

Foreign direct investment in agriculture is mainly concentrated in the countries of Asia and the Americas, given both the existence of fertile arable land and a certain economic, social and political stability conditions specific to the countries in the region compared to the mainland Africa. (Rjoub et al, 2017)

From the point of view of foreign investment in the agro-industrial sector, European countries are the main recipients of the capitals of transnational companies. Mergers and acquisitions or greenfiels investment are fueled, in the case of these countries, by the existence of a large number of consumers with purchasing power, with food preferences for both traditional and eco products, access to the entire European market for products made, but and economic, social and political situation.

Mergers and acquisitions are a way to make foreign direct investment in a host country, which has the advantage of rapid deployment. The use of this method of implementation is generated by factors such as initiation and development of privatization programs or the onset of financial crises that favor the emergence of a large number of private companies that can be taken over at low prices due to financial difficulties (Matei, 2004). The statistical data published by UNCTAD show the reduced use of this method of implantation in the agricultural sector, it being more used in the agri-food sector, where there are companies that have been the subject of international take overs (Figure 1)

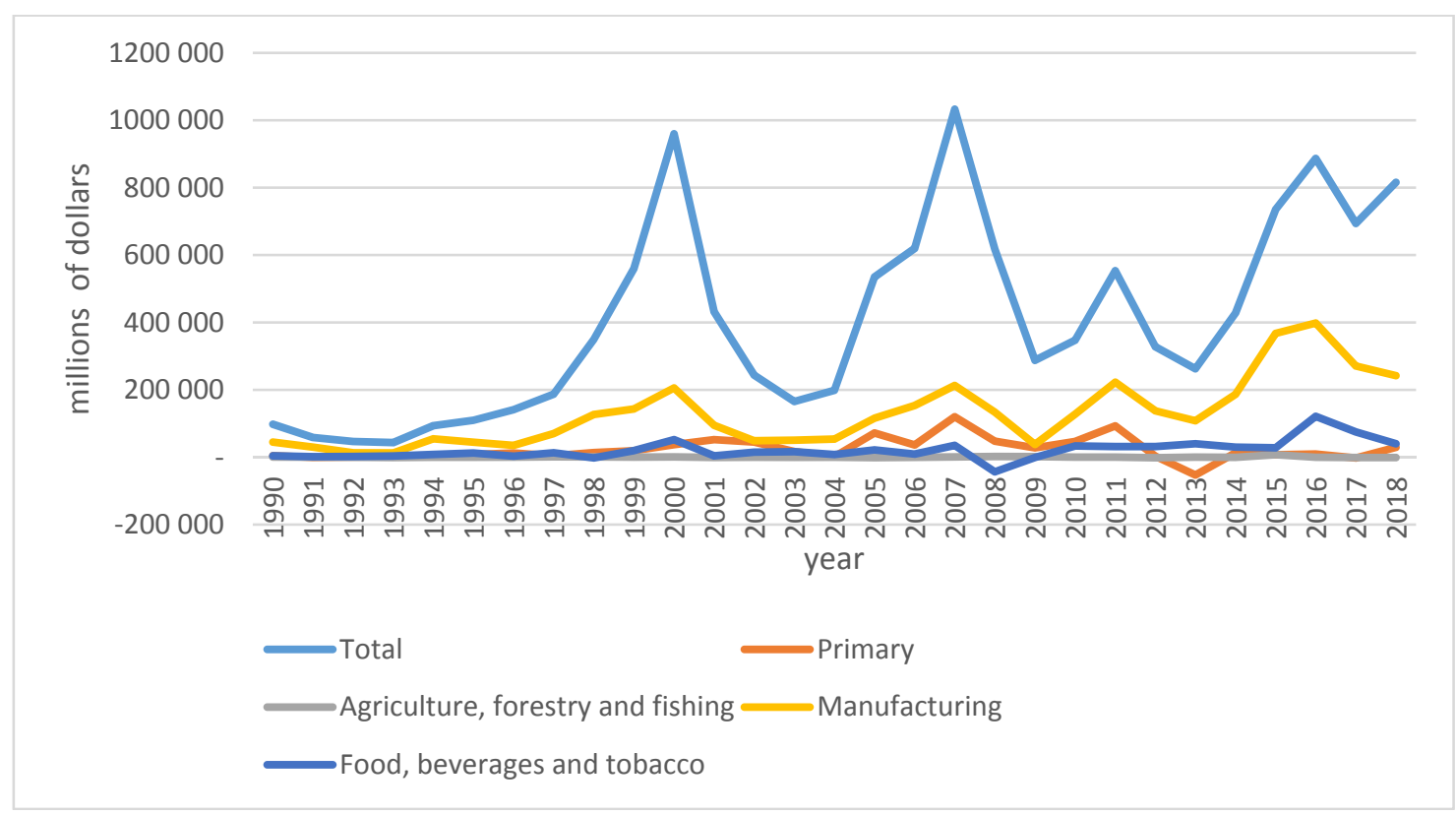

Figure 1: Value of cross-border M\&A purchases, by sector/industry, 1990-2018 Source: authors based on UNCTAD, (2019)

The food, beverage and tobacco sector also stands out through a higher number of mergers and acquisitions, compared to the agriculture sector. Statistical data show the dynamism of this sector, which in certain years has registered more mergers and acquisitions projects and higher values even than the entire primary sector, which in addition to agriculture also includes Mining, quarrying and petroleum (figure 2). 


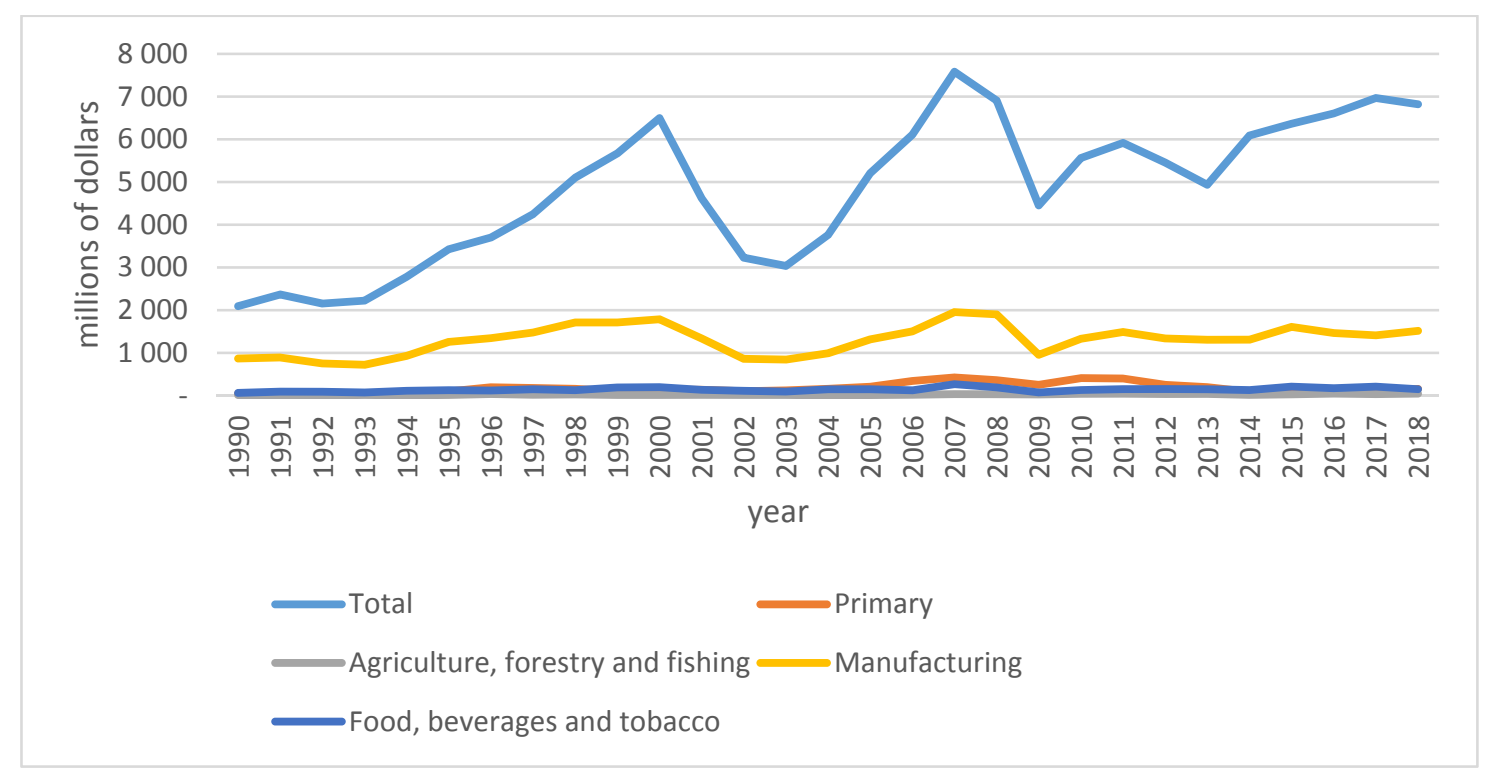

Figure 2: Number of net cross-border M\&A purchases, by sector/industry, 1990-2018 Source: authors based on UNCTAD, (2019)

Greenfield investments (figures 3 and 4) is a preferred way of implantation by certain investors because its have the advantage that the new business is properly sized and developed from the beginning, no longer staff or technology restructuring being neede. The main disadvantage is the longer period of implementation of the investment.

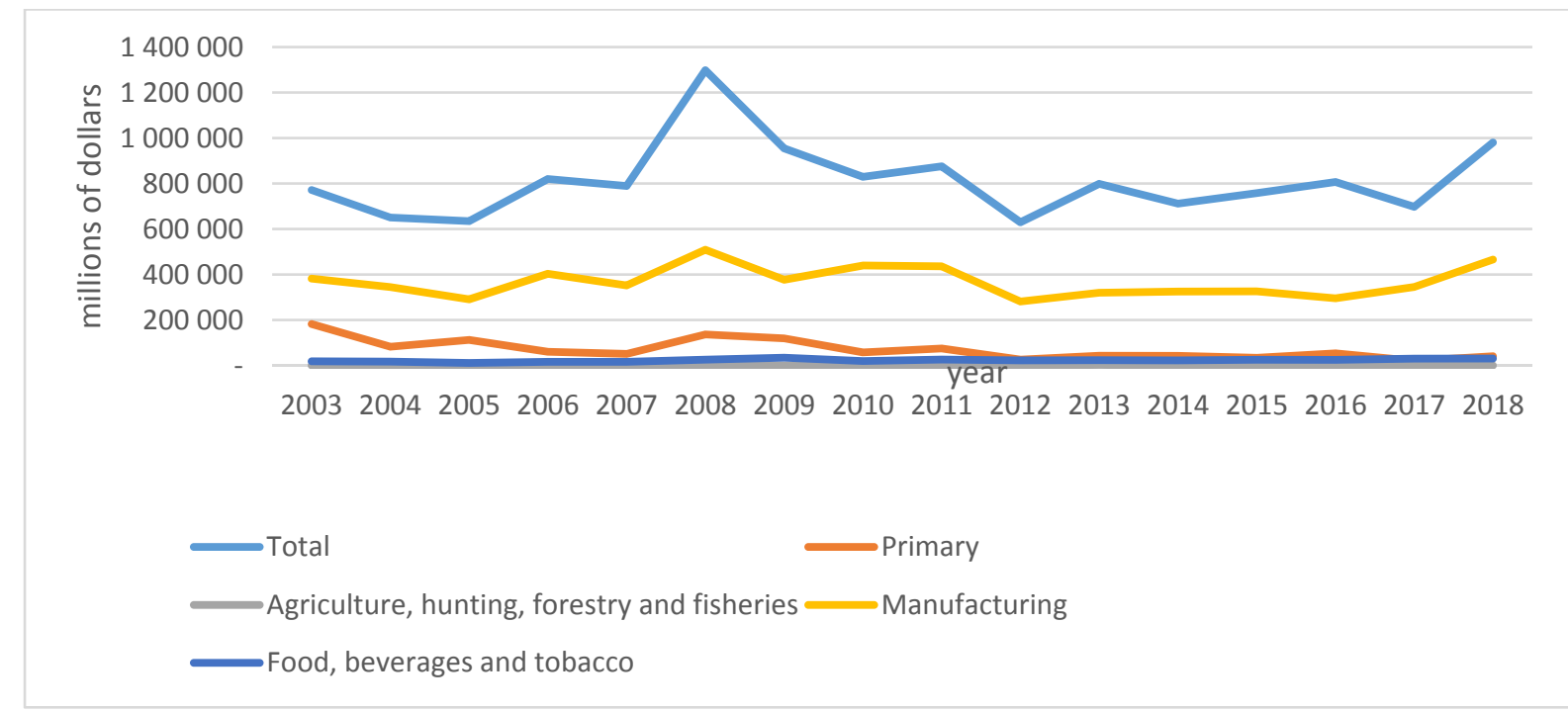

Figure 3: Value of announced greenfield FDI projects, by sector/industry, 2003-2018

Source: authors based on UNCTAD, (2019)

The analysis of statistical data published by UNCTAD demonstrates the concentration of greenfield projects in the secondary and tertiary sector. The annual data place the Agriculture, hunting, forestry and fisheries sector on the last places in terms of the number of greenfield investments. Although the presence of foreign capital is in the agri-food sector modest compared to the services sector, the strength of TNCs has fueled the agro-industrialization process that has led to increased food production and partial resolution of food security investments. 


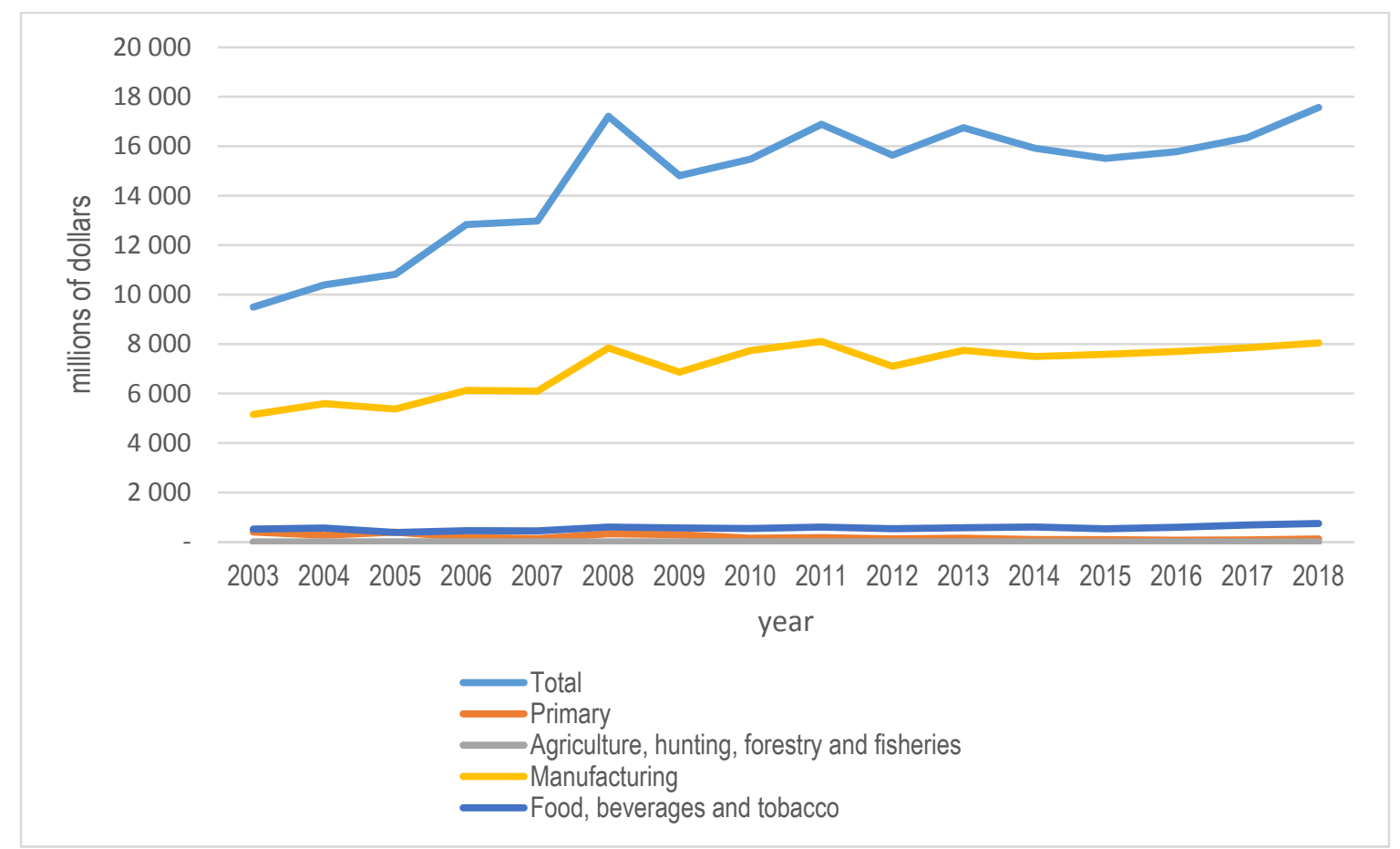

Figure 4: Number of announced greenfield FDI projects, by sector/industry, 2003-2018 Source: authors based on UNCTAD, (2019)

The agro-industrialization process and the existence of the global supply chains created in the food industry also have beneficial consequences on the spread of the concept of CSR on an international level, the transnational corporations being the main promoters. In addition to their own CSR programs that transnational companies initiate and carry out, they could impose codes of conduct on subcontractors or raw material suppliers and promote codes that apply at the level of the field (Matei, 2013; Rueda et. al, 2017).

\section{CSR IMPLICATION IN AGRI-FOOD SECTOR}

The agricultural sector can generate a negative impact on the environment through various mechanisms such as soil degradation, deforestation, greenhouse gas (GHG) emissions, soil and water pollution through the use of fertilizers or pesticides (UNCTA, 2009, Zaman et al, 2020). The degradation of the environment that threatens food security and safety has led to an increase in the concerns of economic agents in agriculture to promote the principles of sustainable development through various mechanisms and instruments, at national, regional and international levels. Climate change generated by environmental pollution has direct consequences on agricultural production, because even small variations in temperature or precipitation can cause considerable losses to agricultural producers. For this reason, local farmers and TNCs have adapted their activities to the new challenges and achieve better water management, use of renewable energy sources in farms and production process, promote pest management

One of the tools of involvement in promoting sustainable development is CSR which reshapes the activities of companies in various fields, especially those that have a negative impact on the environment or local communities (Siano et al, 2010; Palazzo et al. 2016; Deight et al, 2016; Barić et al, 2020). The concept of CSR emerged as a response of companies that realized that maximizing shareholder profit is no longer a strategic goal in a complex world, with multiple interdependencies, shaken by scandals and crises such as food contamination (Ciutacu et al., 2005; Matei, 2013; Brezoi, 2018; Martos-Pedrero et al., 2019; Stancu, 2019).

More and more companies have become aware of their role in the economy, of the negative externalities they generate, which is why they try to enhance their positive impact on society and even contribute to the harmonious development of the communities in which they operate, protect the environment, respect the rights of employees and fight corruption. Socially responsible companies must comply with legal regulations and make additional investment in human capital, the environment and improve their relationships with stakeholders. (Siano et al., 2010; Matei, 2013; Siminica and Sichigea, 2018; Sima and Gheorghe, 2019; Siminica et al., 2015; Nazzaro et al., 2020). In this way, companies are very attentive to the requirements of different categories of stakeholders, given their involvement which are no longer mere spectators of the economic phenomenon, but sanction the inappropriate actions of companies such as those in highly polluting industries or those whose activity has an impact on public health, encouraging their decisions the activity of companies that have adopted the principles of sustainable development. Thus, consumers base their product purchasing decisions on 
issues related to the behavior of manufacturing companies towards the environment, public health or local communities, and portfolio investors consider additional criteria for selling and buying financial securities such as corporate social responsibility, thus fueling the process of divestment from polluting companies and the process of investing in environmentally friendly companies (Panait et al., 2014; Lombardi et al., 2015; Palazzo et al., 2016; Cristea et al., 2020). Reality has shown that CSR is not a simple tool for involving companies in society or in the community, it is not a marketing technique but a component of the management strategy that fuels the company's long-term competitive advantage (Genier et al., 2009; Matei, 2013) by generating favorable attitudes from stakeholders, by creating a business opportunity, by the emergence and integration of new tools through which we witness business reengineering (for example social investment). However, researchers (Panait et al, 2014; Lombardi et al., 2015; Raimi et al., 2015; Palazzo et al., 2016) draw attention to the use of CSR programs as a tool to improve the company's image, without a real involvement of the company in promoting sustainable development principles, in response to pressure from certain stakeholders, mainly NGOs or as a tool to improve consumer loyalty.

The agri-food sector has a huge potential for CSR given the large number of people who are affected by the actions of agri-food companies as buyers, suppliers, rural communities in which they operate In addition, the impact of these companies on the environment is significant both by the negative externalities it can generate and by the positive externalities it achieves (Zaman et al., 2020) and the public goods it provides (Zekić, Bojan Matkovski, 2017) in the form of achievement of food security and food safety, environmental protection of agricultural land, establishment of viable rural communities; biodiversity conservation, preservation of landscape and cultural and historical heritage ofrural areas; Therefore, CRS must be in the agri-food sector a long-term, permanent and proactive strategy (Martos-Pedrero et al., 2019) to ensure the reduction of risks related to future events.

Local communities are a very important category of stakeholders as a target for CSR programs (Deigh et al., 2016). In the case of the agricultural sector, the local communities become even more important considering that they are not only areas that host the development of production activities characteristic of this economic fiels, but they also fulfill specific functions such as providing recreation, sports facilities for urban population, preservation of traditional, cultural and historical values. This situation could generate the transformation of small farms, into a new multifunctional productionservice "enterprise" that promote agricultural and non-agricultural activities. In this way, the farms could move away towards secondary and tertiary activities, generate employment and greater economic self-reliance of rural areas. Therefore, CSR is considered a feasible driver for rural development (Arato et al., 2015) given that through the liberalization of international trade and capital movements local communities have access to new development opportunities but will also be affected by new threats as a result reducing the role of the state in the economy and dominating the agri-food system by transnational companies and small and medium enterprises (Borsellino et al., 2020)

\section{CONCLUSIONS}

This paper evaluated the impacts of the transformation of agri-food sector under the influence of foreign capital and the CSR implication in sector having into consideration the TNCs actions.

Despite of numerous transformations, agriculture continues to be perceived as strategic economic sector in contemporary economies. Analyzing the implication of TNCs in agri-food sector has reviled the existence of a determinant divergence between the CSR approaches and the need for profit. The capital movements could be considered a feasible vector in identifying the most profit rewarding activity, and the agri-food sector has managed to attract significant amount of investments.

Foreign capital attracted to the agri-food sector has a complex impact on host countries, in the sense that in addition to the recognized effects of foreign direct investment, certain specificities can be observed. Rural communities develop both under the direct action of production processes carried out by transnational companies but also through their involvement as beneficiaries of CSR programs carried out by these companies. So, CSR programs run by TNCs are driver for rural development. Although the presence of foreign capital is in the agri-food sector modest compared to the services sector, the strength of TNCs can generate important changes in the economies of host countries regarding food security and health of the population or consumer awareness of food waste.

Economic agents operating in the agri-food sector can be involved through various actions to promote Sustainable Development Goals launched by the United Nations.

Some objectives such as SDG 2: Zero Hunger; SDG 3: Good Health and Well-Being for people; can be achieved either by direct actions, with positive effect, of companies operating in this sector, or indirectly by reducing the negative externalities that generate environmental pollution, health problems of the population due to food contamination. In addition, through CSR programs, agri-food companies contribute to educating consumers that they should be encouraged to reduce food waste. In this way, companies can also make an essential contribution to achieving SDG 12: Responsible Consumption and Production.

Promoting the principles of sustainable development is not the prerogative of public institutions. Private companies and consumers can contribute to supporting the efforts of public authorities through specific measures. Companies could reduce their negative externalities, and consumers must sanction the inappropriate behavior of companies towards different categories of stakeholders through acquisitions. 
Overall, the current research is consistent with previous studies in the field and generates a more visible approach by highlighting both the challenges and effects generated in the process of creating a more responsible agri-food sector.

\section{REFERENCES}

Andrei, J. V., Panait, M., \& Alecu, A. (2015). Transformations of European agricultural sector, market and model under the influence of Common Agricultural Policy (CAP). In International Conference on Competitiveness of Agro-food and Environmental Economy Proceedings (Vol. 4, pp. 137-147). The Bucharest University of Economic Studies.

Anghel, M. G., Anghelache, C., \& Panait, M. (2017). Evolution of agricultural activity in the European Union. Romanian Statistical Review Supplement, 65(6), 63-74.

Arato, M., Speelman, S., \& Van Huylenbroeck, G. (2016). Corporate Social Responsibility applied for rural development: An empirical analysis of firms from the American continent. Sustainability, 8(1), 102.

Aschemann-Witzel, J., De Hooge, I., Amani, P., Bech-Larsen, T., \& Oostindjer, M. (2015). Consumer-related food waste: Causes and potential for action. Sustainability, 7(6), 6457-6477.

Barić, A., Omazić, M. A., Aleksić, A., \& Pejic-Bach, M. (2020). Influence of CSR Activities on Stakeholders in Foreign Markets. In Recent Advancements in Sustainable Entrepreneurship and Corporate Social Responsibility (pp. 16-36). IGI Global.

Bojan, M., Koviljko, L., \& Stanislav, Z. (2017). The foreign trade liberalization and export of agri-food products of Serbia. Agricultural Economics, 63(7), 331-345.

Bolling, C., \& Somwaru, A. (2001). US food companies access foreign markets through direct investment. Food Review/National Food Review, 24(1482-2016-121475), 23-28.

Borsellino, V., Schimmenti, E., \& El Bilali, H. (2020). Agri-Food Markets towards Sustainable Pat

Bowers, J. K., \& Cheshire, P. (2019). Agriculture, the countryside and land use: an economic critique (Vol. 4). Routledge

Brezoi, A. G. (2018). Ethics and Corporate Social Responsibility in the Current Geopolitical Context. Economic Insights Trends and Challenges Vol.VII(LXX) No. 2/2018, $45-52$

Chaudhuri, S., \& Banerjee, D. (2010). FDI in agricultural land, welfare and unemployment in a developing economy. Research in Economics, 64(4), 229-239.

Ciutacu, C., Chivu, L., \& Preda, D. (2005). Company'S Social Responsibility-A Challenge For Contemporary World. Romanian Journal of Economics, $20(1$ (29)), 79-94.

Constantin, C., Luminița, C., \& Vasile, A. J. (2017). Land grabbing: A review of extent and possible consequences in Romania. Land Use Policy, 62, 143-150.

Cristea, M., Noja, G. G., Stefea, P., \& Sala, A. L. (2020). The Impact of Population Aging and Public Health Support on EU Labor Markets. International Journal of Environmental Research and Public Health, 17(4), 1439.

Da Silva, C. A. (2009). Agro-industries for development. CABI.

Da Silva, V. D. P. R., De Oliveira, S. D., Hoekstra, A. Y., Dantas Neto, J., Campos, J. H. B., Braga, C. C., ... \& De Holanda, R. M. (2016). Water footprint and virtual water trade of Brazil. Water, 8(11), 517.

Deblonde, M., De Graaff, R., \& Brom, F. R. A. N. S. (2007). An ethical toolkit for food companies: Reflections on its use. Journal of Agricultural and Environmental Ethics, 20(1), 99-118.

Deigh, L., Farquhar, J., Palazzo, M., \& Siano, A. (2016). Corporate social responsibility: Engaging the community. Qualitative Market Research: An International Journal.

Dusmanescu, D. (2013). Aspects Regarding Implementation of Renewable Energy Sources in Romania up to 2050. International Journal of Sustainable Economies Management (IJSEM), 2(4), 1-21.

Ene, C. (2008). Consumer Behaviour Concerning Post-Consumer Waste. Petroleum-Gas University of Ploiesti.

Ene, C. (2009). Securitatea alimentară-coordonate şi implicaţii. Editura Universităţii Petrol-Gaze din Ploieşti, 162.

Ene, C., Voica, M. C., \& Panait, M. (2017). Green Investments and Food Security: Opportunities and Future Directions in the Context of Sustainable Development. In Measuring Sustainable Development and Green Investments in Contemporary Economies (pp. 163-200). IGI Global.

Genier, C., Stamp, M., \& Pfitzer, M. (2009). Corporate social responsibility for agro-industries development. Agroindustries for development, 223.

Gow, H. R., \& Swinnen, J. F. (1998). How foreign direct investment has stimulated growth in the Central and Eastern European agri-food sectors: Vertical contracting and the role of private enforcement capital (No. 1068-2016-86864). 
Heijman, W., Hagelaar, G., \& van der Heide, M. (2019). Rural resilience as a new development concept. In EU Bioeconomy Economics and Policies: Volume II (pp. 195-211). Palgrave Macmillan, Cham.

Henson, S., \& Cranfield, J. (2009). Building the political case for agro-industries and agribusiness in developing countries. Agro-industries for development, 10-45.

Hughes, D. W. (2019). Financing the agricultural sector: Future challenges and policy alternatives. CRC Press.

Jiang, X., \& Chen, Y. (2020). The Potential of Absorbing Foreign Agricultural Investment to Improve Food Security in Developing Countries. Sustainability, 12(6), 2481.

Lombardi, A., Caracciolo, F., Cembalo, L., Lerro, M., \& Lombardi, P. (2015). How does corporate social responsibility in the food industry matter. New medit, 14(3), 2-9.

Maertens, M., \& Fabry, A. (2019, March). Creating more and better jobs in global value chains. In The Future of Work in Agriculture Conference, Date: 2019/03/19-2019/03/20, Location: Washington DC, USA (pp. 1-24).

Martin, W. (2019). Economic growth, convergence, and agricultural economics. Agricultural Economics, 50, 7-27

Martos-Pedrero, A., Cortés-García, F. J., \& Jiménez-Castillo, D. (2019). The Relationship between Social Responsibility and Business Performance: An Analysis of the Agri-Food Sector of Southeast Spain. Sustainability, 11(22), 6390.

Matei, M. (2004). Foreign direct investments. Functions and evolutions. Bucharest: Expert Publishing House

Matei, M. (2013). Responsabilitatea socială a corporaţiilor şi instituţiilor şi dezvoltarea durabilă a României. Bucharest: Expert Publishing House.

Nazzaro, C., Stanco, M., \& Marotta, G. (2020). The Life Cycle of Corporate Social Responsibility in Agri-Food: Value Creation Models. Sustainability, 12(4), 1287.

Palazzo, M., Vollero, A., Elving, W., \& Siano, A. (2016). Avoiding the greenwashing trap: between CSR communication and stakeholder engagement. International journal of innovation and sustainable development, 10(2), 120-140.

Panait, M., Andrei, J., \& Voica, C. (2016). AGRICULTURAL INVESTMENTS-BETWEEN PROFITABILITY AND SUSTENABILITY. Вестник АПК Ставрополья, (S2), 51-54.

Panait, M., Voica, M. C., \& Radulescu, I. (2014). The activity of capital marketactors: under the sign of social responsibility. Procedia Economics and Finance, 8, 522-528.

Pandey, V., Vidal, N., Panwar, R., \& Nafees, L. (2019). Characterization of Sustainability Leaders and Laggards in the Global Food Industry. Sustainability, 11(18), 5072.

Qiang, W., Liu, A., Cheng, S., Kastner, T., \& Xie, G. (2013). Agricultural trade and virtual land use: the case of China's crop trade. Land Use Policy, 33, 141-150.

Radulescu, I. G., \& Dumbravescu, B. (2008). From GATT to WTO. Petroleum-Gas University of Ploiesti Bulletin, Economic Sciences Series, 60(4).

Raimi, L., Akhuemonkhan, I., \& Ogunjirin, O. D. (2015). Corporate Social Responsibility and Entrepreneurship (CSRE): antidotes to poverty, insecurity and underdevelopment in Nigeria. Social Responsibility Journal.

Reardon, T., Barrett, C. B., Berdegué, J. A., \& Swinnen, J. F. (2009). Agrifood industry transformation and small farmers in developing countries. World development, 37(11), 1717-1727.

Rjoub, H., Aga, M., Abu Alrub, A., \& Bein, M. (2017). Financial reforms and determinants of FDI: evidence from landlocked countries in Sub-Saharan Africa. Economies, 5(1), 1.

Rueda, X., Garrett, R. D., \& Lambin, E. F. (2017). Corporate investments in supply chain sustainability: Selecting instruments in the agri-food industry. Journal of cleaner production, 142, 2480-2492.

Santangelo, G. D. (2018). The impact of FDI in land in agriculture in developing countries on host country food security. Journal of World Business, 53(1), 75-84.

Siano, A., Siglioccolo, M., \& Palazzo, M. (2010). A comparative analysis between US and Italian food companies on stakeholder relationships via websites. International Journal of Electronic Customer Relationship Management, 4(2), 180-195.

Sima, V., \& Gheorghe, I. G. (2018). Trends in the Evolution of Organic Food Market in Romania. International Journal of Sustainable Economies Management (IJSEM), 7(2), 45-55.

Sima, V., \& Gheorghe, I. G. (2019). Customer Satisfaction in the Consumption of Green Products. In Green Business: Concepts, Methodologies, Tools, and Applications (pp. 1161-1194). IGI Global.

Siminica, M., \& Sichigea, M. (2018). Corporate Social Responsibility as a Voluntary Initiative But a Mandatory Nonfinancial Reporting Link Between the Social and Financial Performance of Romanian Companies. In Current Issues in Corporate Social Responsibility (pp. 77-96). Springer, Cham. 
Siminică, M., Crăciun, L., \& Dinu, A. (2015). The impact of corporate sustainability strategies on the financial performance of Romanian companies in the context of green marketing. Amfiteatru Economic Journal, 17(40), 9941010.

Slimane, M. B., Huchet-Bourdon, M., \& Zitouna, H. (2016). The role of sectoral FDI in promoting agricultural production and improving food security. International economics, 145, 50-65.

Sodano, V. (2019). Innovation Trajectories and Sustainability in the Food System. Sustainability, 11(5), 1271.

Stancu, A. (2012). Food and Feed Safety in Romania in the European Union Context: Current Issues. Petroleum-Gas University of Ploiesti Bulletin, Technical Series, 64(3), 2012-3.

Stancu, A. (2019). Asf Evolution And Its Economic Impact In Europe Over The Past Decade. The USV Annals of Economics and Public Administration, 18(2 (28)), 18-27.

Vasile, A. J., \& Ungureanu, A. (2014). The importance of economic structure evolution in achieving performance-from agrarian economy to competitiveness in Romanian economy. Economics of agriculture, 61(4), 945-957.

Voica, C., \& Panait, M. (2017). Steps to liberalization of international trade with agricultural products. Sustainable agriculture and rural development in terms of the Republic of Serbia strategic goals realization with the Danube region-development and application of clean technologies in agriculture-thematic proceedings, 309-325.

Yao, H., Alhussam, M. I., Abu Risha, O., \& Memon, B. A. (2020). Analyzing the Relationship between Agricultural FDI and Food Security: Evidence from Belt and Road Countries. Sustainability, 12(7), 2906.

Zaman, G., Panait, M. C., Voica, M. C., \& Ene, C. (2020). Corporate Social Responsibility in the Agri-Food Sector. In Recent Advancements in Sustainable Entrepreneurship and Corporate Social Responsibility (pp. 37-68). IGI Global.

Zekić, S., \& Matkovski, B. (2017). Sustainable development of agriculture in Serbia as a function of rural development. Sustainable agriculture and rural development in terms of the Republic of Serbia strategic goals realization with the Danube region-development and application of clean technologies in agriculture-thematic proceedings, December 2016, Belgrade, Serbia, 254-269.

FAO, (2020). FAOSTAT, Foreign Direct Investment (FDI), retrieve from: http://www.fao.org/faostat/en/\#data/FDI/visualize, accessed: [12.03.2020].

UNCTAD (2019). World Investment Report: Annex Tables, retrieve from: https://unctad.org/en/Pages/DIAE/World\%20Investment\%20Report/Annex-Tables.aspx, accessed: [12.03.2020]. 